\title{
住民参加の公園づくりについてーワークショップによるプロセスプランニングの事例としてー* Effect of Workshop with Process Planning on Neighborhood Park *
}

\author{
古賀貴典**坂本紘二***·外井哲志****・武林晃司***** \\ By Takanori KOGA** Koji SAKAMOTO ${ }^{* \star *} \cdot$ Satoshi TOI ${ }^{\star \star \star \star} \cdot$ Koji TAKEBAYASHI $^{\star \star \star \star \star *}$
}

\section{1.はじめに}

まちづくりや公園整備等において, 住民参加によ る計画づくりにワークショップ (以下, WS と記す) が昨今盛んに実施されるようになった ${ }^{1)}$. 多様な主 体間の意見が共有され合意形成が促され，参加意欲 が醸成される点で，WS は有用な手法である ${ }^{2)}$. そ の他に一般的に，多様な意見や情報を収集できるこ と, 参加者の気づき, 理解, 知識が増進し対象への 意識が変容すること，あるいは，管理や活用等に対 する協働意識が増進し，パートナーシップの輪が形 成されること等が WS の効果として指摘されている 3).また，公共事業を進める際の住民参加の計画づ くりにおいて，住民だけではなく行政や専門家の意 識変容に向かう上での有効な手法として, WS が求 められている4)。

福岡市南区の長丘中公園では, 基本構想の策定か $ら$, 基本設計・実施計画案づくり, 基盤整備の工事 施工に到るまで, その都度, 住民参加のWS を重ね, さらに詳細な施設整備については, 実際に利用しな がら住民たちの意向に沿って進めていく非決定の 「プロセスプランニング手法」が採られている.WS による住民の意識変容や合意形成を指摘した研究は 多く, また公園整備の各段階においてWS で取り組 まれた事例もさまざまである ${ }^{1)}$. しかし，本例のよ うに各段階をカバーしながら, 行政上の予算執行措 置のしくみまでも合意形成のプロセスに含め, また 住民が公園を利用しながら工事にも参加し, さらに は住民による自発的な維持管理がなされるといった 一貫した動的な流れを持った WS の事例は希有であ ると言ってよい。

本研究は, この計画手法を用いた長丘中公園再整 備において，長期に及んで重ねられたWS の経過を 通して，段々と親密感の濃い公園になっていく過程 を追究することで, これからの施設整備の計画手法

*キーワーズ : 公園・緑地, 市民参加

**学生会員, 九州大学大学院工学府都市環境システム工学専攻 (福 岡市東区箱崎 6-10-1 TEL092-641-3131 内線 8656)

***正会員，下関市立大学(下関市大学町 2-1-1 TEL0832-52-0288 ダイヤルイン 54-8652 FAX0832-52-8099)

****正会員, 九州大学大学院工学研究院（福岡市東区箱崎 6-10-1 TEL092-642-3277 FAX092-642-3277)

*****非会員, (株) 緑景九州事務所 (福岡市中央区舞鶴 3-7-13 大禅

ビル TEL092-713-8765 FAX092-713-8759)
として「プロセ

スプランニング

手法」が有効で

あることを示す

と共に，住民参

加WSを進めて

ゆく上での効果

と問題点を明ら

かにしようとす

るものである。

2.WS 開催の発

端と公園の概要

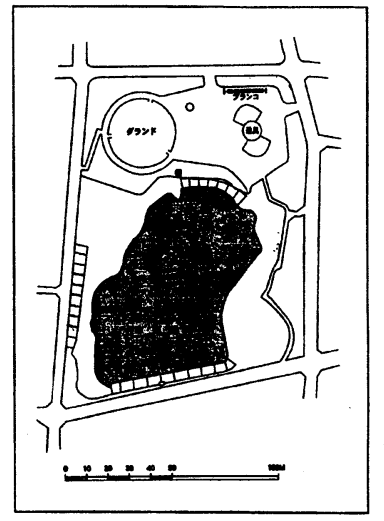

図-1工事前の市楽池と公園

長丘中公園

$\left(10,700 \mathrm{~m}^{2}, 1968\right.$ 年に開園した近隣公園）に隣接 する市楽池 $\left(5,200 \mathrm{~m}^{2}\right)$ は, 以前農業用溜池として 使われ, 都市化進展後は洪水調整池（調整容量 $15,500 \mathrm{~m}^{3}$ ) の役割を果たしている(図-1).この 池と長丘中公園とが一体となった公園の再整備計画 の中で, 1989 年に市楽池を「運動場兼治水池」とす る整備案が作成されたが, 自然保護を唱える住民か らの反対に遭って白紙に戻され, その後長年の懸案 事項となっていた.そして「市民主体のまちづくり の実現」をめざして 1996 年度に始まった福岡市の 地域づくり推進事業の中で, 南区地域づくり協議会 が 1997 年度事業における実際的な取り組みの一つ として, 合意形成を図りながらこの公園再整備に活 かしていこうと, 地域住民参加による池と一体とな った公園の構想案づくりのWS が開催されることに なった。

\section{WSの経過}

長丘中公園 WS では，これまでの 6 年間，6 ラウ ンドの, 延べ回数にして 20 回を超える WS が行わ れた。第 1 ラウンドと第 2 ラウンドで 4 回, 第 3 ラ ウンドと第 5 ラウンドで 3 回, 第 4 ラウンドで最多 の 7 回, 第 6 ラウンドで最少 2 回の WS が開催され ている. 第 1 ラウンドでは基本計画案 (図-2), 第 2 ラウンドでは基本設計の案 (図 -3 ), 第 3 ラウン ドでは市楽池部分の実施設計の案 (図-4), 第 4 ラ ウンドでは北側長丘中公園部分の実施設計の案（図 
-5）がそれぞれ相次いで作られた。さらに第 5 ラ ウンドでは，それまでに完了した工事についての反 省と住民が参加できる工事が行われ, 第 6 ラウンド では, 設計案と食い違った部分を含めて, 手直し工 事について議論された。詳細は表一1 のとおりであ る.図-6 は長丘中公園計画平面図である。なお, 長丘中公園 WS は 2002 年 10 月をもって一旦終了し た。

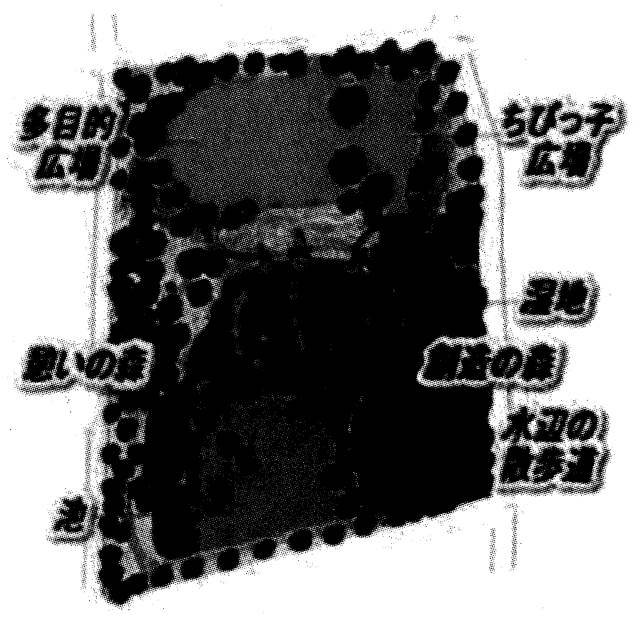

図-2 長丘中公園基本計画案

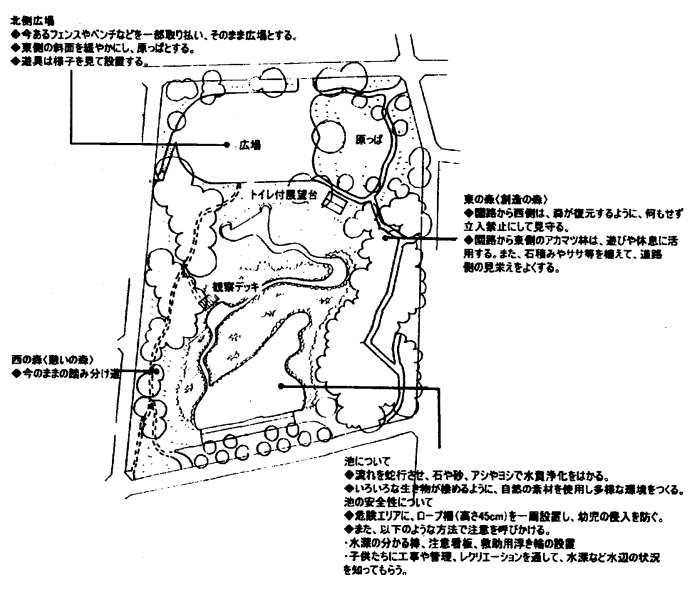

図-3 長丘中公園基本設計

表-2 工事の進め方

\begin{tabular}{|c|c|c|}
\hline \multirow{2}{*}{ 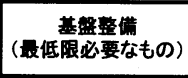 } & 1期(2000年) & 工事参加イベントー锤察会 \\
\hline & 2期（2001年） & エ事参加イベント・穊察会 \\
\hline \multirow{3}{*}{$\begin{array}{c}\text { 施設整供 } \\
\text { （必要な施設の追加） }\end{array}$} & 3期（2002年） & ワークショップと設計 \\
\hline & 4期（2003年） & ワークショシプと設竍 \\
\hline & 5期 $(\cdots \cdots)$ & ワークショップと設計 \\
\hline
\end{tabular}

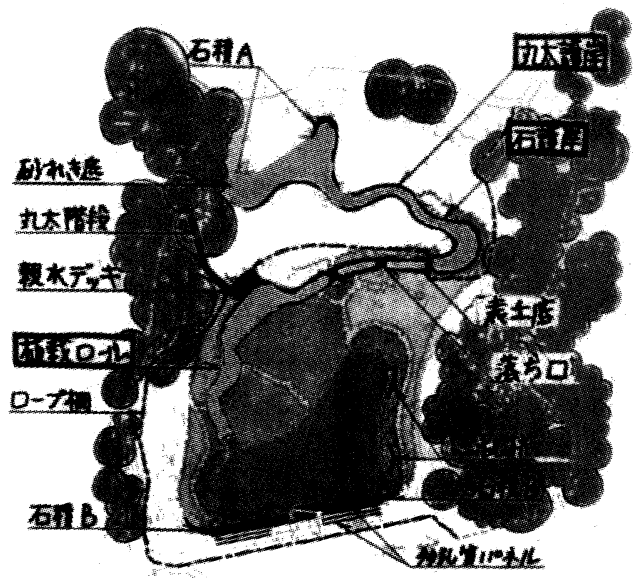

図－4 市楽池実施設計平面図

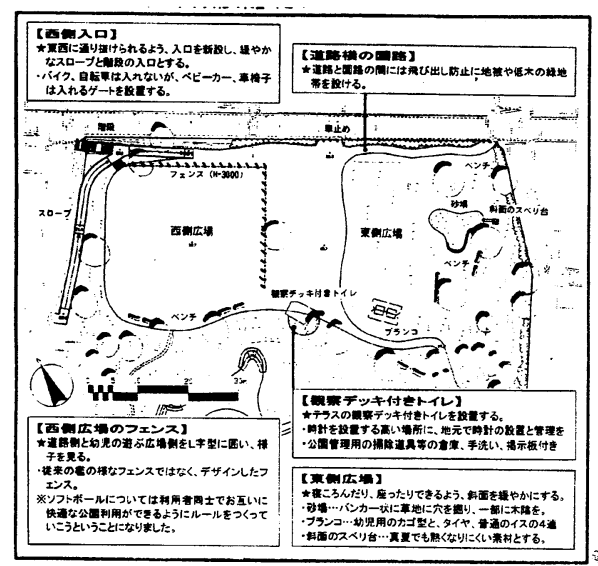

図-5 長丘中公園改修案

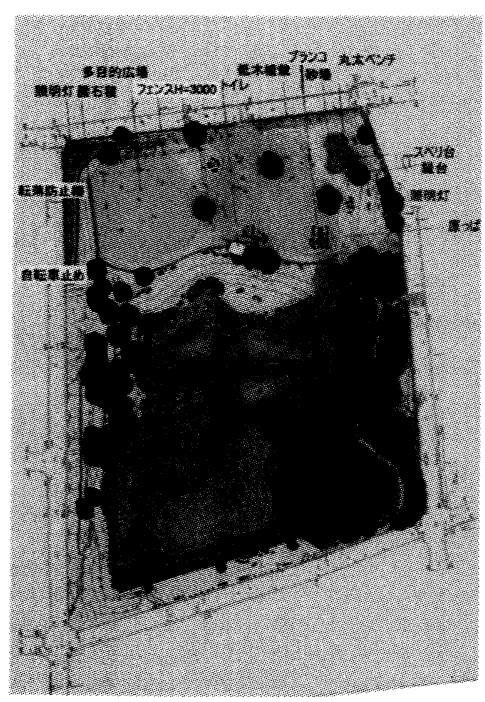

図－6 長丘中公園計画平面図 


\begin{tabular}{|c|c|c|c|c|}
\hline ワークショップと目樶 & 開催時期 & 回数 & 解要 & 主な内容 \\
\hline \multirow[t]{4}{*}{ 1. 基本椎想のプランつくり } & \multirow{4}{*}{\begin{tabular}{c|}
1997.1 \\
$\sim 1998.1$
\end{tabular}} & 第1回 & 現地調查 & 参加者のほとんどがWSに対する夦いを持っていた。 \\
\hline & & 第2回 & 基本方吽、基本イメージの検討 & 一部の参加者から進め方に対する不満が出る。 \\
\hline & & 第3回 & 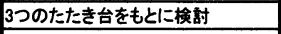 & 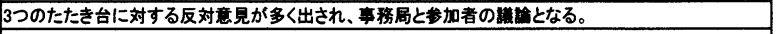 \\
\hline & & 第4回 & 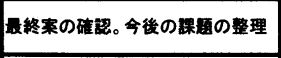 & 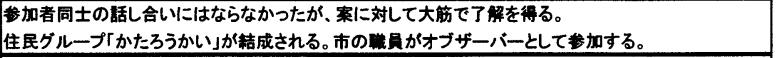 \\
\hline \multirow[t]{4}{*}{ 2. 基本設計をまとめる } & \multirow{4}{*}{$\begin{array}{c}1999.4 \\
\sim 1999.8\end{array}$} & 第1回 & 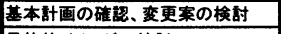 & 動植物調查、测荁の結果を情䡋として提伴する。 \\
\hline & & 第2回 & 具体的イメージの検封 & 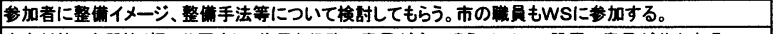 \\
\hline & & 第3回 & たたき台をもとに検討 & 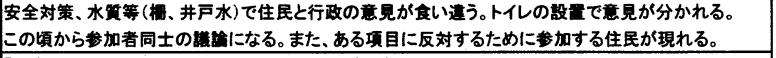 \\
\hline & & 第4回 & 細部の検封。最終案の確视 & 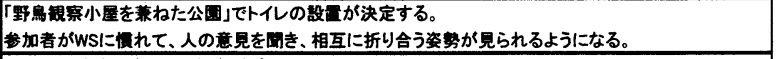 \\
\hline \multirow[t]{3}{*}{ 3. 池のエ事チェックと㐱加 } & \multirow{3}{*}{$\begin{array}{l}1999.11 \\
\sim 2000.3 \\
\end{array}$} & 第1回 & 英施設計説明 & 池部分の造成工事。表土保全がポイント。 \\
\hline & & 第2回 & 工事説明会、費重種の移植 & 贯重な植物等(ツクシオオカヤツリ、タツツボスミレ、フレリンドウ)の移植を羍者と住民がー粕に行う。 \\
\hline & & 第3回 & 青重程の移植 & 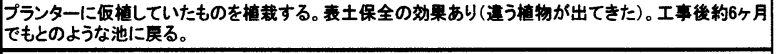 \\
\hline \multirow[t]{7}{*}{ 4. 施設等实施設計委づくり } & \multirow[t]{7}{*}{$\begin{array}{l}2000.7 \\
\sim 2001.3\end{array}$} & 第1回 & 子供ワークショップ & 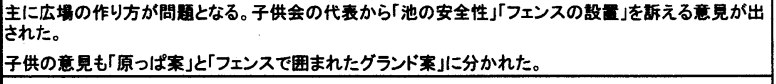 \\
\hline & & 第2回 & 基本設計の見直し検討 & 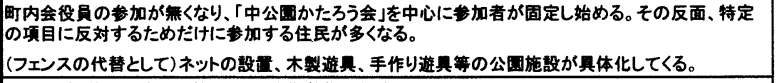 \\
\hline & & 第3回 & たたたき台をもとに検封。綱部の検封 & 使いながら施設を徐々に整えて行く長期擎傮の提実。 \\
\hline & & 第4回 & 最終寀の確刧 & 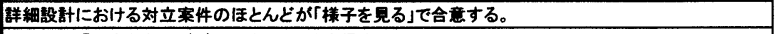 \\
\hline & & 第5回 & 实施設計競明会 & フェンスは「目立たないデザイン」とし、了承を得る。 \\
\hline & & 第6回 & 工事説明会。貫重種移植 & 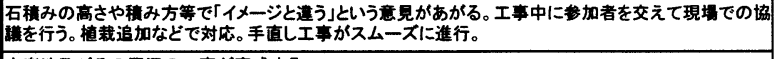 \\
\hline & & 第7回 & 责重種移植 & 市楽池及びその周辺のエ事が完成する。 \\
\hline \multirow[t]{3}{*}{ 5. 工事後の第1回 } & \multirow{3}{*}{$\begin{array}{c}2001.9 \\
\sim 2002.3 \\
\end{array}$} & 第1回 & 工事が終わっての反省 & しギュラーメンバーのみの如。工事担当者も反省会に参加。 \\
\hline & & 第2回 & 工事説明会。貫重種移植 & 様々な要望のうち一部を今年度エ車に反映し、その他は様子を見ることにする。 \\
\hline & & 第3回 & しがら組 & $\begin{array}{l}\text { 人の侵入で荒れた西の森をきれいにするためしがらを組む。林料は工事費に入れ、能加者が労カを提 } \\
\text { 供する。 }\end{array}$ \\
\hline \multirow[t]{2}{*}{ 6. 工事後の第2回 } & \multirow{2}{*}{\begin{tabular}{r|r|}
2002.6 \\
$\sim 2000.10$ \\
\end{tabular}} & 第1回 & 手直し工事の数明 & \\
\hline & & 第2回 & エ事が終わっての反省 & \\
\hline
\end{tabular}

\section{4. 公園整備の進め方}

基本設計策定の第 2 ラウンドの段階で，遊具など の施設については，実際に使ってみて様子を見なが ら必要とされるものを徐々に整えていくやり方が提 案されていた。実施設計を定める第 4 ラウンドの 3 回目の WS（以下，「4-3WS」のように記す）で， 今回の工事の進め方は, $2 \sim 3$ 年で終わらせてしまう 通常の工事ではなく,まず 2 年の内に最低限必要な 基盤整備的なものまで工事を行い，さらに必要な施 設類については，WS 等を重ねながら工事内容を定 め， 5 期まで追加工事していくことが決定された. 表-2 に示すような, 実際に使ってみながら必要な 設備を徐々に整えて行くというプロセスプランニン グの手法が, 幾段階にも及んでその都度開催された WS の過程で採用されることになったのである.

当初の基本計画づくりの段階では, 残されている 池や森の部分の自然をできるだけ残し，将来的によ り自然度が高まるような整備を行うことで意見の一 致をみたものの, 北側の公園広場における「トイレ」, 「遊具」,「フェンス」などの各論に相当する詳細部 分の設計に関しては意見の対立が表面化した。しか し，最小限の整備で使いながら考え合うことで合意 形成が徐々に得られるようになった。
筆者らは，伝統的に継承されてきた水利技術に見 出される特質の一つとして, 時間経過の中で変動を 体験する度に修復を経て段々と整い, 自然のリズム を獲得して安定し歳月とともに親しみや豊かさが増 していくようなありようを取り上げ,「成っていく構 造」と称している ${ }^{5)}$. 長丘中公園再整備の進め方は, それと同じような質を持った，時間経過とともに親 密度が増す持続性を求めうる施設整備への計画手法 と技術の展開であると考えられる ${ }^{6)}$.

\section{5. 調査の概要}

本研究を行うにあたり，住民，行政担当者，コン サルタントに対して，アンケート調査やヒアリング 調查を行った。調查目的は，長丘中公園が “他の公 園整備のモデル”となりうるまでの成果が得られた 要因と実際の効果面の把握や，WS 手法の問題点や 改善点の明確化を行うためである，調查方法は，住 民に対しては, 最終 WS の参加者 10 人にアンケー 卜調査, さらに, レギュラーメンバーで「かたろう 会」のメンバーでもある 5 人にヒアリング調查を行 った. 行政に対しては，長丘中公園WSに関わった 行政担当者 12 人にヒアリング調査を行った.また, 長丘中公園 WS の運営に携わったコンサルタント 1 名にヒアリング調查を行った。調査項目は，個人属 
性, 参加状況, 長丘中公園の利用について,「長丘中 公園 WS の体験」について,「WS のあり方について」 等である。

\section{6.住民参加 WS の効果}

長丘中公園 WS の経緯を表ー1 に示した.この公 園再整備 WS の特長は, 構想案づくりから種々の工 事に至るまでさまざまな段階毎に長期にわたって幾 度もWS を重ねてきていることである. 長丘中公園 WS の運営に関わったコンサルタント及び行政担当 者, 参加住民へのヒアリング結果から, 住民参加の WS でもたらされた効果について整理すると，主な ものとして以下の 5 点がある.

\section{（1）参加住民と行政担当職員の意識の変容 (a)参加住民の意識変容}

まず，住民の意識変容が挙げられる，最初の 11WSでは, 参加者のほとんどが既に案ができていて， 形だけの市民参加ではないかと不信感が強かった。 続く 1-2WS でも，「幼稚に見えるWS 手法への不 満」や「既に案ができているという疑い」等から， 一部の参加者から進め方に対する不満の表明が続い ていた、経過等を率直に説明し, 参加者の合意によ る案の策定であることに理解を求め, 参加者はひと まず納得し，互いに少しずつ慣れてきた。 1-3WS では, それまでの参加者の議論を整理して提示した 3 つの案に対して, 参加者同土での議論よりも, ま だたたき台を提案した事務局と参加者とのやり取り やグループ内での議論が主となり，1-4WS で構想 案の合意は得られたものの, 全体的な参加者同士の 議論にならないという状況が続いたまま, 第 1 ラウ ンドは終了した。参加者同士の相互の検討が進み, 本音の意見が飛び交うようになったのは，2-3WS 辺りからであり, 2-4WS では, 参加者が他者の意 見を聞きながら折り合う姿勢も見られるようになっ た. 充実した進行に慣れるのには積み重ねとある程 度時間経過が必要だといえる。

また, 進行の過程で, 参加者の構成も微妙に変化 している４-2WS からそれまで住民参加の呼びか けにも熱心でずっと参加していた町内会役員の参加 が減り，住民グループ「かたろう会」を中心に参加 者が固定し始め, その後は参加者がほとんどレギュ ラー化するようになった.これは, 対立を生んでい た調整池に関する議論が一段落し, 池の姿が明確に なったためでもあった. そうした流れの中で，2$3 W S$ ではトイレの設置に反対するためや 4-2WS ではフェンス設置を要求する目的のみで参加する住 民も現れたりするが, 特段紛紏することなく, 参加
者同士それまでの過程を踏まえての粘り強い議論が できるようになっていた。

\section{(b)行政担当者の意識変容}

行政担当者の参加は 1-4WS からであった.その 段階では福岡市公園建設課がオブザーバーとして参 加し, 調整池担当の河川建設課の参加はなかった. 設計案づくりに入った第 2 ラウンド以降のWS は担 当課が主宰していた.どちらの担当課も WS には当 初オブザーバーとして参加していたが，2-2WS か らは，オブザーバーとしてではなく，WS のテーブ ルの中に入ってもらい立場を同じにした。 それによ って関係がほぐれ，相互の率直な意見交換が可能に なり，時に，「安全対策」「「水質」等の専門的なテ一 マの際には, 行政担当者が専門家として情報や見解 を提供するようになった。

特に 2-3WS では,「柵は不要」とする市民と「管 理上, 柵は必要」とする行政との間で意見の食い違 いが生じたが, 結論を持ち帰り,「公園管理課」,「公 園建設課」,「河川建設課」の 3 者が十分に議論した 結果,「護岸を緩やかにする」,「柵を低くする」など の折襄案が出され，参加者に受け入れられている. 行政担当者は場面に応じて参加者と専門家の二つの 役割を担い, 相互の信頼関係が構築できていた。そ のために完了した池の工事をチェックし議論し合う 5-1WS にも担当した職員が参加し, 厳しい指摘に たじろきながらも意見や要望を受け止めて今後に活 かすというオープンで前向きの姿勢に変わっていた． 行政にも意識変容があったことを示すものである.

\section{（2）対立点の克服}

参加者同士が対立し合意形成が困難に思われたの は,「トイレ」と「フェンス」の設置の有無に関する 問題であった。

(a)トイレの設置について

2-3WS でのトイレの設置に関して,「臭い」,「景 観が悪い」,「ホームレスや不良の溜まり場になる」 といった感情的な意見が出て, 当初は反対が大多数 だった.議論をしていくうちに変化が見られたが, 賛成と反対は半々に分かれ，そのまま期間をおくこ とにした。約一ヶ月後の $2-4 \mathrm{WS}$ では, 事務局が「人 間の生理から考えたトイレの必要性」の報告や「公

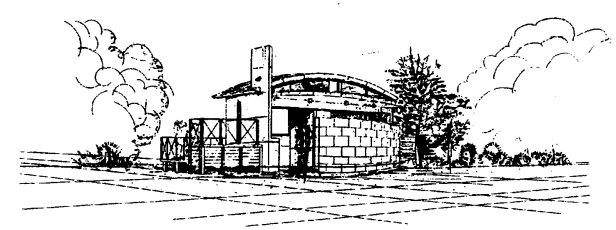

図ー7 野鳥観察小屋を兼ねたトイレ 
園利用者へのアンケート」および「他の公園の設置 事例，管理状況，事例写真」等の情報提供を行った 結果，設置賛成が増えたが，反対もまだ少なくなか った。その段階で模型を囲んでの意見交換の場で「野 鳥観察小屋を兼ねたトイレ」(図一7)の提案が出て, それによって設置場所も含めての合意が得られた。 (図-3,5,6参照)

(b)フェンスの設置について

基本設計では既存のフェンスを取り払つた自由な 「原っぱ」

にすること になってい た.第 4 ラ ウンドでは, それまで

WS に参加 してなかっ た子供会の

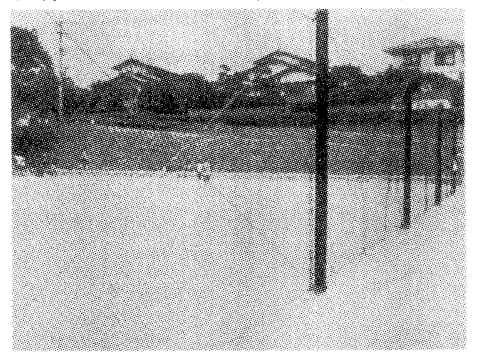

図ー8 デザイン性のあるフェンス
代表等から「池の安全性」,「フェンスの設置」を訴 える意見が出され, 広場で遊ぶ子供達の意見も「原 っぱ案」と「グランド案」に分かれていた。フェン スの代替としてネットの設置や彫刻的なデザイン性 があるものなどの意見も出たが，4-2WS まで意見 はまとまらなかった。4-3WSでは前述したような 長期整備の進め方が決定されたこともあって, 後に 片側の部分的な目立たないデザインのフェンス（図 -8）設置で様子を見ながら整備を進める案で合意 している。フェンス以外の詳細設計で多くの食い違 いが生じていたが，4-4WS で「旗揚げアンケート」 の項目に「様子を見る」を追加したことによって， 意見が対立した項目のほとんどがソフトランディン グすることになる。

以上のことから, 結論が出ず白熱した時には無理 に解決しようとせずに，時間を置くことが大切だと いうことがよく分かる。その間に, 参加者の折禹案, アイデアが出され, 必要とされる情報提供も行われ る.また,逆にあらかじめ回数を決めておくことも， 合意形成を達成する上では必要なことである。現に 1-4WS では構想づくりの最終回ということで大筋 の了解が得られ, 細部は今後の課題として整理され た.2-4WSでも最終回ということで全ての問題に おいて合意を得ている。状況に応じて持ち越しを重 視したり，回数を決めたりといった多様な進め方が 合意形成には必要であるといえる。

\section{（3）経費の削減}

従来の手法では, 自治会長に説明する際, 良さそ うなもの，素人が見てそれなりのものをつくってい
たが,今回は「柵 はロープで良 い」など，無駄 なものに金をか けず，費用の削 滅に繋がった。 第 5 ラウンドで は,「しがら組」 （図一）を行 ったが，ここで は，材料費のみ を工事費に入れ， 参加者が労力を 提供するという 形だった。維持 管理についても， 簡単な掃除など は地域住民が行

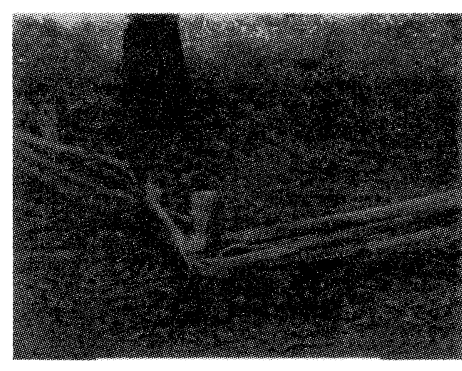

図-9 しがら組

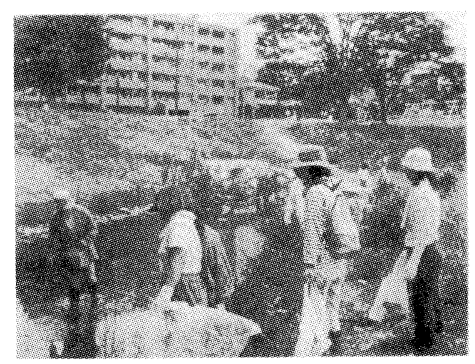

図-10 市楽池の掃除風景 つており（図-10），経費削減に繋がっている。

\section{(4) 学習の場の形成}

(a)住民の学習

WS は様々なジャンルの人とお互い知り合う機会 となり，新たな人間関係が築ける。それにより，い ろんな知識が得られるほか，人の意見を聞いたり， 自分の意見を理解してもらったりするプロセス（議 論の仕方）が実感として分かる。また, 様々な行事 に参加することで顔なじみも増え，地域や行政との 関わりを経験できる。

\section{(b)行政担当者の学習}

それまで，文献でしか学習していなかったWSを 実際に経験することにより, 合意形成過程を直接体 験できることは，行政担当者にとってかなり有益で ある. その他にも, 専門家とのコラボレーションの 仕方などが分かってくる.

また，住民の公園への熱意や WS への思いに感動 したり,いろんなイベントで生物の説明を聞いたり, 植物の移植をするなど, 自分がやったことがない体 験ができるといった仕事以外の面で, 行政担当者に とってかなりのプラスになる。

\section{（5）参加意識の醸成}

\section{(a)環境に対する意識変容}

WS に参加することで，以前より公園について身 近に考えるようになったり，鳥や虫，植物など身近 な自然への開眼が起きたりする。また，公園に対す る愛着も湧いてくる。行政担当者にとっても,「あの ような場所に自然が残っていると思わなかった。」と いうような発見がある。 


\section{表-3 住民参加WS の問題点とその解決法}

\begin{tabular}{|c|c|c|}
\hline & \begin{tabular}{|l|l} 
& 問題点 \\
\end{tabular} & 解決法 \\
\hline \multirow{3}{*}{ 参加の範囲 } & $\begin{array}{l}\text { (1) 参加意識の向上 } \\
\text { ·参加者は高齢者や主婦が大部分で，サラリーマンや学生の } \\
\text { 参加はほとんととない. } \\
\text { ·WSに来ている人だけで住民参加が実現しているとはいえな } \\
\text { い. }\end{array}$ & 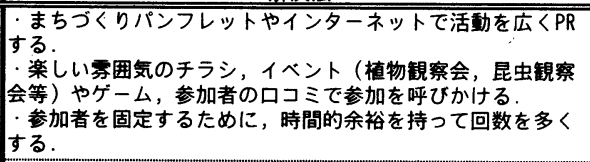 \\
\hline & $\begin{array}{l}\text { (2) 不特定多数の参加者 } \\
\text { ·参加者が少なければ, WSで決まったことが住民の総意であ } \\
\text { るとはいえない. } \\
\text { ·新しい参加者の要望で基本楎想や理念が変更されたり，議 } \\
\text { 論の蒸し返しが起こったりして，継続性がなくなる. }\end{array}$ & $\begin{array}{l}\text { •それまでの内容を毎回丁實に振り返る. } \\
\text { ·WS当日に簡単な確認を行う. }\end{array}$ \\
\hline & $\begin{array}{l}\text { (3) 役職者の不参加 } \\
\text { 地域の問題であるにもかかわらず，自治会長などの役職者が } \\
\text { 不参加 }\end{array}$ & $\begin{array}{l}\text { 役職者を中心にある程度参加者を固定した上で自由参加を } \\
\text { 募る. }\end{array}$ \\
\hline \multirow[t]{2}{*}{ 条件の明確化 } & $\begin{array}{l}\text { (1)WSの動機付け } \\
\text { ·何のためにWSをするのかという動機付けが不明確になって } \\
\text { いる. } \\
\text { ·少数意見を無視して多数決で決めるのであれば, WSをやっ } \\
\text { ている意味がい. } \\
\text { ·近隣住民の利害損得により,ことが処理されている. }\end{array}$ & 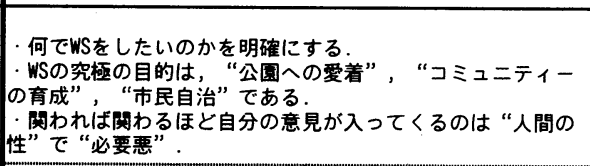 \\
\hline & $\begin{array}{l}\text { (2) 他の手法との併用 } \\
\cdot \text { 近年はWSがブームになっているが, WSもパーフェクトでは } \\
\text { ない. }\end{array}$ & $\begin{array}{l}\text { WSはあくまでもまちづくりのー手法である. } \\
\text { ·WSだけではなく, 町内会レベルでー旦議論を持ち㷌る. } \\
\text { ·自治会, 子供会, 老人会などの諸団体に議論してもらう. } \\
\text { ·周辺住民にはは個別にアンケートを行って正確な意見を把握 } \\
\text { する. }\end{array}$ \\
\hline \multirow{3}{*}{ 情報伝達 } & $\begin{array}{l}\text { (1) 住民への情報不足 } \\
\text { ·行政担当者は十分に情報提供を行ったと思っているが，住 } \\
\text { 民は全員が情報不足だと思っている. } \\
\text { ·議事録がなかった. }\end{array}$ & $\begin{array}{l}\text { ·WS開催の案内, プランの進み具合などを回覽や広報誌で広 } \\
\text { く広報する. } \\
\text { · マスコミを活用してWSをアピールする. } \\
\text { · 子供の総合学習を通して情報を伝える. } \\
\text { - 議事録を作る. }\end{array}$ \\
\hline & $\begin{array}{l}\text { (2) 双方向の情報伝達 } \\
\text {. 行政サイドの情報提供が主で，住民からの情報提供はな } \\
\text { かった. }\end{array}$ & $\begin{array}{l}\text { 使い心地や季節の変化等に関する情報については, より } \\
\text { 知っている住民から引き出す. } \\
\cdot \text {-WSでは常に双方向の情報提供が必要. }\end{array}$ \\
\hline & $\begin{array}{l}\text { (3) 行政内部の情報伝達 } \\
\text {. 行政の引継ぎが不十分だったために, 残す方針だった森の } \\
\text { 木が一部伐採された. }\end{array}$ & 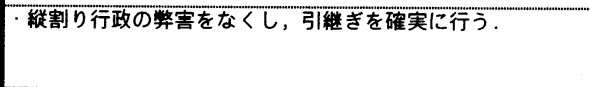 \\
\hline WSの認知 & $\begin{array}{l}\text { ·WSをスムーズに進行させる手立てが+分でない. } \\
\text { ·日本人は小さいときから「自分たちで動かしていく」とい } \\
\text { う意識が薄い. }\end{array}$ & $\begin{array}{l}\text { - 費用や時間，人員など，必要に応じて迅速に対応できる体 } \\
\text { 制にする. } \\
\text {-「自分たちでつくるのだ」という意識付けを行い，説明会 } \\
\text { 手法のように“文化”にしていく. } \\
\text { ·経験を積んでいくことで社会的に広く認知を得る. }\end{array}$ \\
\hline 住民の課題 & $\begin{array}{l}\text { ·熱心な人とそうでない人（参加者と不参加者），昔から住 } \\
\text { んでいる人と新しい人とのギャッブが大きい. } \\
\cdot \text { 参加したくても，開催場所や日時の都合で参加できない住 } \\
\text { 民がいる. } \\
\text { ·WSが終わってから行政を捕まえて意見を言う人がいる. }\end{array}$ & $\begin{array}{l}\text { ·あらゆるギャップをなくすためにも, 住民同士コミュニ } \\
\text { ケーショシをうまくする. } \\
\text { ·積極的にWSに参加する. } \\
\text { ·忙しい時間帯を避け，土日など比較的時間があるときに開 } \\
\text { 催する. } \\
\text { ·WSに慣れ，意見はWSの中で述べる. }\end{array}$ \\
\hline \multirow{4}{*}{ 運営上の課題 } & $\begin{array}{l}\text { (1) 人材の確保と育成 } \\
\text { ·WSの内容を把握していない. } \\
\text { ·住民の質問にきちんと答えられない. } \\
\text { ·住民の個人的な要望で基本方針を曲げる. } \\
\text { ·要望やアンケートの反映の仕方が適切でない.（住民の意 } \\
\text { 見やファシリテーターを操作等) }\end{array}$ & $\begin{array}{l}\text { ·WSの内容の周知徹底を計る. } \\
\text { ·もつとWについて衔識や技術を身につける. } \\
\cdot \text { ·意見をなるべく公平な形で吸い上げる. }\end{array}$ \\
\hline & 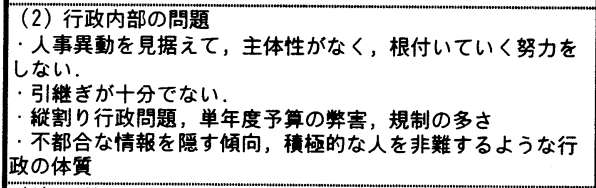 & $\begin{array}{l}\text { 担当者が変わることは止むを得ないが, 行政は100\%の引継 } \\
\text { きをする. } \\
\text { ·WSに対応できるように, 行政組織を改善する. }\end{array}$ \\
\hline & $\begin{array}{l}\text { (3) 予算不足 } \\
\text { ·コンサルタント（民間）への委託料（約50万/1回）が大き } \\
\text { な負担 } \\
\text { ·住民の要望に答えるための工事賽がかかる. }\end{array}$ & ·住民や行政が自ら進行できるようになるのが理想的 \\
\hline & $\begin{array}{l}\text { (4) 行政担当者の悩み } \\
\text {. 行政の人員不足 (特に，技術担当職員は掛け持ちが多い) } \\
\text { ·行政職員への時間的負担が大きい.（業務の増加，休日出 } \\
\text { 勤等) } \\
\text { ·個人的意見と行政人としての意見のバランスが困難 }\end{array}$ & $\begin{array}{l}\text { 十分な人員を投入できるような体制作りをする. } \\
\cdot \text { WW手法を用いる事業を取捨選択する. } \\
\cdot \text { 経験を積むことで行政担当者がWに慣れる. }\end{array}$ \\
\hline 専門家の課題 & $\begin{array}{l}\text { ·住民への説明が不十分で，質問にもきちんと答えられな } \\
\text { い. } \\
\text { ·住民が良いと言えば，つい雾囲気に流されてしまいがちに } \\
\text { なる. }\end{array}$ & $\begin{array}{l}\text { ·アドバイスできるようなノウハウを持っている人が専門家 } \\
\text { として参加する. } \\
\text { ·安全管理など専門家の見解が求められるときは, きちんと } \\
\text { 意見を言う. }\end{array}$ \\
\hline \multirow{2}{*}{$\begin{array}{l}\text { ファシリテーター } \\
\text { の課題 }\end{array}$} & $\begin{array}{l}\text { (1) ファシリテーターの育成 } \\
\text {-WSをうまく道けるファシリテーターがあまりいない. }\end{array}$ & $\begin{array}{l}\cdot \text { ファシリテーターの育成（動機付けや知識の周知, 中立の } \\
\text { 維持, 議論すべき事柄の判断, 妥協点のない議論の対処法, } \\
\text { 柔軟性等) }\end{array}$ \\
\hline & $\begin{array}{l}\text { (2) 素賈があるファシリテーターの確保 } \\
\text { ·参加者の数が多くても, 発言者が少なく，笑いがないよう } \\
\text { な暗い旁囲気ではうまくはいかない. }\end{array}$ & $\begin{array}{l}\text { 素賃がある人（面白い人）をファシリテーターに選任す } \\
\text { る. }\end{array}$ \\
\hline
\end{tabular}


(b)まちづくり全体への関心のきっかけ

参加住民に今後の WS の参加の有無について尋ね たところ, 約 75\%の住民が「参加する」と答えた. 参加する理由として,「WS って本当は何かを知りた い.」,「議会民主制だけでは足りない.WS はそれを 補完する取り組みだから。」など前向きな意見が挙げ られた。行政担当者についても, 自分の居住地での WS の参加の有無について尋ねたところ,「積極的な 役割は果たせないが，そういう場があれば参加す る.」,「主体的に関わりたいから参加したい.」,「フ アシリテーターの役割を勉強してみたい.」など積極 的な答えだった. WS は今行っている事業のみなら ず，まちづくり全体への関心のきっかけをつくると いえる。

\section{7. 住民参加 WS の問題点}

長丘中公園 WSに参加した住民と行政担当者を対 象にしたヒアリング結果から，住民参加の WS の問 題点とその解決法について整理すると, 表一 3 のよ うになる. 主なものとして以下の 3 点について説明 する。

\section{（1）参加の範囲や条件の明確化}

(a)参加意識の向上

現在, WS の参加者は高齢者や主婦が大部分で, サラリーマンや学生の参加はほとんどない。だから といって，WS に来ている人だけで住民参加が実現 していると判断するのは甘い。様々な人から意見を 聞いてこそ，本当の住民参加であるといえる．まち づくりパンフレットやインターネットで活動を広く PR したり, みんなで楽しい雾囲気のチラシを作っ たりして, 参加を呼びかける必要がある.そして, とにかく 1 回でも参加させることが, 住民の意識向 上に繋がる，そのために，植物の観察会，昆虫観察 会などのイベントやゲームをWS に盛り込んだり， 参加者の “ロコミ”で不参加者に雾囲気を伝えても らったりすることも重要である。さらに, 参加者を 固定するには，時間をかけた方がよい，時間的余裕 を持って回数を多くすれば，たとえ 1 回用事で出ら れなくても次から参加できるからである.

(b)不特定多数の参加者

WS の大きな問題の一つとして参加者が不特定多 数だということが挙げられる.参加者が少なければ, WS で決まったことが住民の総意であるとはいえな い. また，テーマによって出席者の顔ぶれが極端に 変わり, 新しい参加者の要望でそれまで構築された 基本構想や理念が変更されたり，議論が蒸し返され たりすることで, 継続性がなくなる.そうならない
ためにも，それまでの内容を毎回丁寧に振り返った り，WS 当日に簡単な確認を行ったりしていくべき である。

\section{(c) WS の動機付け}

何のためにWS をするのかという動機付けが不明 確になっていることが少なくない。少数意見を無視 して多数決で決めるのであれば，WS をやっている 意味がなくなる. 関われば関わるほど自分の意見が 入ってくるのは “人間の性”で “必要悪”ではある が，公園を庭の一部として暮らしている近隣住民の 利害損得によりことが処理されるのはかなり問題が ある. 何でWS をしたいのかを明確にする必要があ る.WS の究極の目的は, “公園への愛着”, “コミュ ニティーの育成”などである。

\section{(d)他の手法との併用}

近年はWS がブームになっているが，WS はあく までもまちづくりの一手法である。WS だけではな く, 自治会, 子供会, 老人会などの諸団体に議論し てもらったり, 周辺住民には個別にアンケートを行 ったりして正確な意見を把握する必要がある.

\section{（2）情報伝達}

\section{(a)住民への情報不足}

行政担当者の半数が, ニュースレターや揭示板で 情報提供は十分に行ったと思っているが，住民は全 員が情報不足だと思っている。「月 1 回の WS の情 報提供は手が回らなかった.」という行政担当者の本 音の声も挙がっている。議事録がないというのもお かしい. WS 開催の案内はもちろん, プランの進み 具合などを回覧や広報誌で広く広報していく必要が ある。また，マスコミを活用してWS をアピールし たり，子供の総合学習を通して情報を伝えたりする のも有益かもしれない。

\section{(b)双方向の情報伝達}

情報提供というと行政や専門家から住民へすべき ものと考えている参加者も少なくない。しかし, 普 段利用している住民の方が行政や専門家よりも情報 を持っているということもあり得る，例えば，使い 心地や季節の 変化等に関す る情報である。 逆にそれらを 引き出すプロ グラムもあれ ばより充実し た内容の議論 に結びつくと 考えられる。

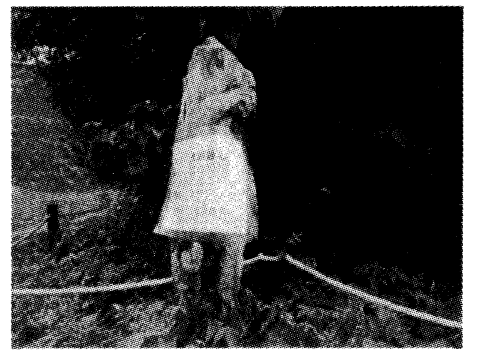

図ー11 伐採された記念の木 
WS では常に双方向の情報提供が必要であるといえ る。

\section{(c)行政内部の情報伝達}

長丘中公園 WS において, 構想案では残す方針だ った森の木が一部伐採される事件が起きた（図一 11).WS に参加しなかった 町内役員の要望に行政 の公園管理の部署が応じたためだった。住民の反対 で伐採は中断されて大事には至らなかったが, 情報 伝達がうまくできていれば防ぎ得た事態である・「縦 割り行政」の弊害をなくし，情報伝達を確実に行う 必要がある。

\section{（3）WS の認知}

現在，WS をスムーズに進行させる手立てが十分 でない。現在の状況では，費用や時間，人員などを 考えると, 必要に応じて迅速に対応できる体制とは とても言い難い，それに，日本人は小さいときから 「自分たちで動かしていく」という意識が薄い。一 方で, 説明会手法は相当昔からあり,一種の“文化” になっている。「自分たちでつくるのだ」という意識 付けを行い，WS も“文化”にしていかなければな らない。数多く積み重ねて経験を積んでいくことで 社会的に広く認知を得る必要があるといえる.

\section{8. おわりに}

本研究から，住民参加による施設整備における参 加者同士の合意形成には，ある場合には決定を急が ないで時間を置きながら進めることが必要なこと, 各WS で場面に応じうる柔軟な対応が求められるこ となどが明らかになった.また，WS を普及させるた めには余裕のある進行管理への行政内部のシステム 転換, 住民へのWS の認知などが必須であるといえる. 本研究のモデルとなった長丘中公園は「プロセス プランニング手法」を用いて整備された。プロセス
を含んだ整備の進捗は，公園としての機能を十分に 発揮して, “親密感の濃い利用度の高い公共の場”を 形成するに違いない.実際, 2003 年 1 月 29 日には, 観察会や維持管理等の長丘中公園に関する地道な活 動が評価され,「福岡市都市景観賞」の特別表彰を受 けた.長丘中公園 WS は 2002 年 10 月をもって一旦 終了したが，公園の維持管理や運用面に関わるよう になる住民意識の生成など今後の経過で WS の本当 の意味での成果が表れるものと考えられる.

そして, 長丘中公園再整備のように持続性のある 進め方には,これからの公共空間の整備に必要とさ れる計画手法と技術の展開が示されている．また， WS によるまちづくりは公園だけではなく，生活道 路，公民館など生活に密着した施設や溜池，河川な どの身近な自然，あるいは，マスタープラン，空き 教室の利用といったソフト的なものまで応用できる. 多くの公共施設がその利用者によるWSを通して整 備される日々が来るのも遠くはないのかもしれない.
参考文献
1) 建設省関東地方建設局国営昭和記念公園工事事務所監 修·公園緑地管理財団編「協働】による公園づくり読本一 住民と共に考える公園づくり一」大蔵省印刷局 (2000.5)pp15-18,付属資料 pp1-25，事例編 pp.55-123 2) 興儀·坂本·辰巳·古川・浜田「住民参加型公園づくりにお けるWS の有用性」土木学会西部支部研究発表会 (2000.3)pp.764
3) 宮本·道上·喜多·檜谷「河川整備計画の策定における住 民参加に関する一提案」土木計画学研究・講演集 $\mathrm{Na}$ 23(1)(2000.11)pp. 39-42
4) 村田·延藤「参加型計画づくりにおける住民と行政の意 識及び計画内容の変容過程についての考察ＷSによる都 市計画道路及び水辺空間整備計画策定(柳井市)を事例とし て一」2000 年度第 35 回日本都市計画学会学術研究論文 集.pp865-870
5) 坂本・外井「筑後川中流域における水利の技術システム の変遷に関する研究」土木史研究 No.14(1994.6) pp. 77-92
6) 坂本·外井・武林「住民参加の公園づくりについてーWS によるプロセスプランニングの事例としてー」土木学会西 部支部研究発表会(2001.3)pp.B252-253

住民参加の公園づくりについてーワークショップによるプロセスプランニングの事例としてー*

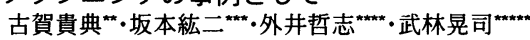

公園整備等において，ワークショップ（以下，WS）が近年盛んに実施されるようになった．福岡市南区の長丘中公園では， 全段階で住民参加のWS を重ね, 実際に利用しながら住民たちの意向に沿って進めていく非決定のプロセスプランニングの手 法が採られた. 本研究は, プロセスプランニングの手法の有効性を示すことと住民参加WS の課題の明確化を目的としている. 本研究から, 合意形成には柔軟な対応が求められることなどが明らかになった。また，WS を普及させるためには適切な行政 内部のシステム転換，WS の認知などが必須であるといえる．持続性のある進め方には，これからの公共空間の整備に必要と される計画手法と技術の展開が示されている.

\section{Effect of Workshop with Process Planning on Neighborhood Park *}

By Takanori KOGA ${ }^{* *} \cdot$ Koji SAKAMOTO ${ }^{* * *} \cdot$ Satoshi TOI ${ }^{* * * *} \cdot$ Koji TAKEBAYASHI ${ }^{* * * * * *}$ In city planning workshop is often carried out in recent years. In the Nagaoka-naka park workshop held in Minami-ku, Fukuoka-city, the technique of the non-determining process planning was adopted from basic plan to construction. The aim of this research is to show the validity of process planning and the problems concerning workshop. It became clear through this research that it is necessary to correspond flexibly for agreement of participants, etc. Moreover, the change for suitable administration system, and the cognition of a workshop are essential in order to spread the workshop. The planning technique, needed for planning of the public space for the future, is shown by the durable procedure. 